MATEC Web of Conferences 40, 01001 (2016)

DOI: $10.1051 /$ matecconf/20164001001

(C) Owned by the authors, published by EDP Sciences, 2016

\title{
Design and Fabrication of Low Cost Thick Film pH Sensor using Silver Chlorinated Reference Electrodes with Integrated Temperature Sensor
}

\author{
Goib Wiranto ${ }^{1}$, Novrita Idayanti ${ }^{1}$, Yuyu Rachmat Tayubi ${ }^{2}$ and Dimas Sukma Batara ${ }^{2}$ \\ ${ }^{1}$ Research Center for Electronics and Telecommunication, Indonesian Institute of Sciences (LIPI), Bandung 40135, Indonesia \\ ${ }^{2}$ Department of Physics Education, Indonesian University of Education, Bandung 40154, Indonesia
}

\begin{abstract}
This paper describes the design and fabrication of thick film $\mathrm{pH}$ sensor, in which the reference electrode has been formed by chlorination of $\mathrm{Ag}$ using $\mathrm{FeCl}_{3}$. The process was aimed to replace $\mathrm{Ag} / \mathrm{AgCl}$ paste commonly used as reference electrodes. Fabricated using thick film screen printing technology on $\mathrm{Al}_{2} \mathrm{O}_{3}$ substrate, the pH sensor showed a measured sensitivity of $-52.97,-53.17$ and $-53.68 \mathrm{mV} / \mathrm{pH}$ at $25{ }^{\circ} \mathrm{C}, 45{ }^{\circ} \mathrm{C}$, and $65{ }^{\circ} \mathrm{C}$, respectively. The measured values were close to the theoretical Nernstian slope of $-59 \mathrm{mV} / \mathrm{pH} 25^{\circ} \mathrm{C}$. The sensor was also designed with an integrated Ruthenium based temperature sensor for future temperature compensation. The measured resistance temperature characteristics showed a linear reasponse over the range of $25-80{ }^{\circ} \mathrm{C}$. This miniaturised planar sensor should find wide application, especially in field water quality monitoring, replacing their glass type counterparts.
\end{abstract}

\section{Introduction}

Nowadays, water quality monitoring requires real time data in which mesurement must be performed in situ/online from a remote location. River monitoring, marine, aquaculture, agriculture, and mining are among the areas where online water quality monitoring have been widely implemented [1-4]. Sensors employed in such application thus need to be compact, rugged and robust to withstand harse environmental condition. Thick film technology offers the possibility of fabricating sensors on planar substrates using wide selection of materials, resulting in miniature devices at low fabrication cost [5].

One parameter of interest in water quality monitoring is $\mathrm{pH}$. As a measure of the acidity and alkalinity of water, the role of $\mathrm{pH}$ in controlling the aquatic life in water is very important [6]. One of the most common techniques in $\mathrm{pH}$ determination is by using electrochemical sensors, where a pair of electrodes are compared for their potentiometric responses. One of the electrodes serves as a reference and the other serves as a working electrode. Usually, materials used for reference electrodes are $\mathrm{Ag} / \mathrm{AgCl}$, due to their stability, performance, and safety against environmental issues [7].

In today's $\mathrm{pH}$ electrochemical sensors, however, the relatively high cost of $\mathrm{Ag} / \mathrm{AgCl}$ reference electrode material [8] has become a problem that needs to be solved either by replacing with different material, or by finding an alternative method for its preparation. In addition, the variation of $\mathrm{pH}$ values against temperatures [9] has made the sensor fabrication increases due to the need for a temperature compensation circuit.
In attempts to improve the performance of a $\mathrm{pH}$ sensor, previous works have included fabrication of $\mathrm{Ag} / \mathrm{AgCl}$ electrode using screen printing technique [1012], deposition by electrochemical process of $\mathrm{Ag}$ and $\mathrm{AgCl}$ onto graphite [13], the use of various metal oxides as $\mathrm{pH}$ electrodes [14-17], and the application of nanotube based electrodes [18]. Although some materials have proved to be a good candidate for $\mathrm{pH}$ reference electrode, however, none of the methods has yet produced a satisfactory cost over preformance results.

This research offers a method by which $\mathrm{Ag} / \mathrm{AgCl}$ reference electrode can be produced by chlorination of Ag using $\mathrm{FeCl}_{3}$, resulting in a sensitive $\mathrm{pH}$ reference electrode. Fabricated using thick film technology, a $\mathrm{pH}$ sensor integrated with Ruthenium based temperature sensor can be batch fabricated on $\mathrm{Al}_{2} \mathrm{O}_{3}$ substrate. This paper will describe the design, fabrication, and the results of characterisation of the sensor.

\section{Design and fabrication}

The sensor device has been designed tofit on a $10 \times 25$ mm alumina $\left(\mathrm{Al}_{2} \mathrm{O}_{3}\right)$ substrate. Device dimension was optimised to allow for ten devices to be simultaneously fabricated on a $50 \times 50 \mathrm{~mm} \mathrm{Al}_{2} \mathrm{O}_{3}$ substrate. As shown in Figure 1, the structure consists of $\mathrm{Ag} / \mathrm{AgCl}$ reference electrode, AgPd working electrode, $\mathrm{KCl}$ electrolyte, Ruthenium based active layer and temperature sensor, and dielectric passivation layer. The use of Ruthenium as an active layer for $\mathrm{pH}$ sensor has been demonstrated [19] in the previous work. The minimum linewidth and spacing for the conductive electrode tracks and resistive temperature sensor are $300 \mu \mathrm{m}$ and $500 \mu \mathrm{m}$, respectively. 
The solder pads were designed as $2 \times 2 \mathrm{~mm}$ each size, and all the structures are contained within $0.8 \mathrm{~mm}$ from the edges of the substrate to allow for safety when the cutting is done manually using diamond scrubber.

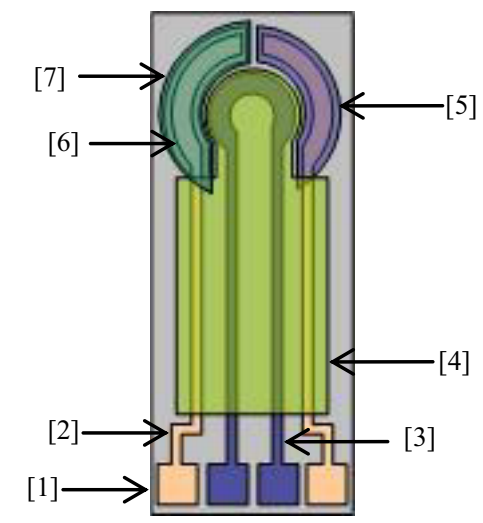

Figure 1. The structure of thick film based $\mathrm{pH}$ and temperature sensors designed on a $10 \times 25 \mathrm{~mm}$ alumina substrate: [1]. Alumina substrate $\left(\mathrm{Al}_{2} \mathrm{O}_{3}\right)$, [2]. Working Electrode (AgPd), [3]. Temperature Sensor $\left(\mathrm{RuO}_{2}\right)$, [4]. Dielectric, [5]. Active layer $\left(\mathrm{RuO}_{2}\right)$, [6]. Reference Electrode $(\mathrm{Ag} / \mathrm{AgCl})$, [7]. Electrolyte

$(\mathrm{KCl})$

Fabrication of the sensor device was started by screen printing AgPd conductor paste (ESL ElectroScience) used as electrodes on a $50 \times 50 \mathrm{~mm}, 96 \% \quad \mathrm{Al}_{2} \mathrm{O}_{3}$ substrate. After printing, the tracks were dried at $100{ }^{\circ} \mathrm{C}$ for $5 \mathrm{~min}$, followed by cooling at room temperature. The second step was screen printing a Ruthenium Dioxide (ESL ElectroScience) resistor paste used as the active layer of the working electrode and the temperature sensor. The resulting structure was then fired using conveyor belt furnace for $45 \mathrm{~min}$ with a peak temperature of $850{ }^{\circ} \mathrm{C}$. Figure 2 shows the resulting structure after firing process. Passivation of the conductor and resistor tracks was done by screen printing a dielectric layer (ESL ElectroScience 4608), followed by drying at $100{ }^{\circ} \mathrm{C}$ for $5 \mathrm{~min}$. The substrate was then cleaned by ultrasonic for $5 \mathrm{~min}$, and each device was cut manually using a diamond cutter.

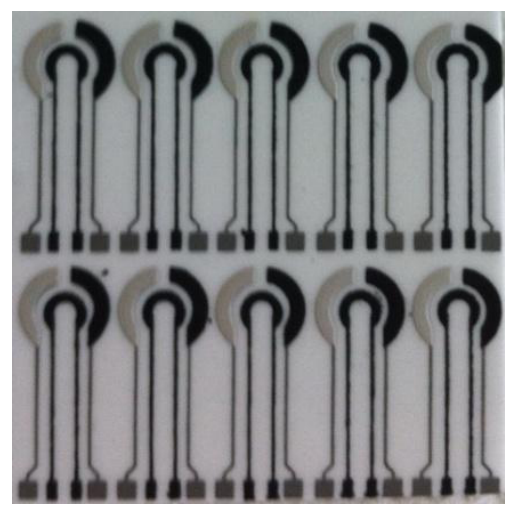

Figure 2. The resulting screen printed conductor AgPd and resistor $\mathrm{RuO}_{2}$ tracks after firing process.

To form a $\mathrm{Ag} / \mathrm{AgCl}$ reference electrode, the top side of the AgPd conductor track was printed with an Ag paste
(ESL ElectroScience), followed by drying at $100{ }^{\circ} \mathrm{C}$ for 15 min. Chlorination of the Ag layer was done by dipping the chip into $0.05 \mathrm{M} \mathrm{FeCl}_{3}$ solution for $50 \mathrm{~s}$ and then rinsing in a deionised (DI) water. As has been demonstrated previously [20], this technique should produce a fast and uniform coating of $\mathrm{AgCl}$ having particle sizes in the order of nanometer. The immersion of $\mathrm{Ag}$ inside $\mathrm{FeCl}_{3}$ solution produces $\mathrm{AgCl}$ according to the following reaction:

$$
\mathrm{Ag}+\mathrm{FeCl}_{3} \longrightarrow \mathrm{AgCl}+\mathrm{FeCl}_{2}
$$

Layer of homogeneous $\mathrm{AgCl}$ should form at the surface of the $\mathrm{Ag}$ layer forming $\mathrm{Ag} / \mathrm{AgCl}$ reference electrode.

The final step in the formation of the reference electrode was to apply a $\mathrm{KCl}$ electrolyte layer over the $\mathrm{Ag} / \mathrm{AgCl}$ layer. A $3.5 \mathrm{M} \mathrm{KCl}$ solution was prepared from $15.65 \mathrm{~g}$ crystalite $\mathrm{KCl}$, added by $60 \mathrm{ml}$ water. Magnetic stirring at room temperature for $15 \mathrm{~min}$ was done and 7\% (by weight) of gellatine was added to the mixture to increase the adhesivity of the $\mathrm{KCl}$ solution. $\mathrm{The} \mathrm{Ag} / \mathrm{AgCl}$ electrode layer was then dipped into the $\mathrm{KCl}$ mixture for $1 \mathrm{~min}$, and then dried at $100{ }^{\circ} \mathrm{C}$ for $5 \mathrm{~min}$. Figure 3 shows the final device structure.

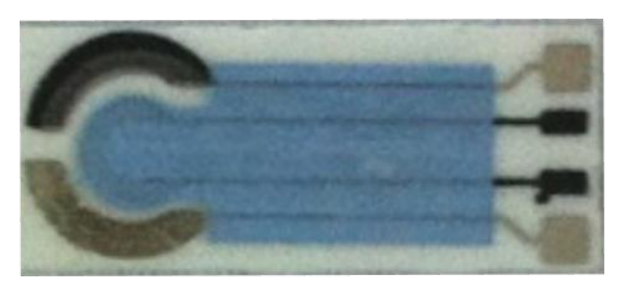

Figure 3. Final device structure after formation of $\mathrm{KCl}$ layer over $\mathrm{Ag} / \mathrm{AgCl}$ reference electrode.



Figure 4. Experimental setup for temperature sensor characterisation using a hotplate and a digital multimeter.

\section{Device characterisation}

Device characterisation was performed in two steps. Firstly, the temperature sensor was characterised to find their resistance temperature characteristics. The aim was to find a linear relationship that will be used for constructing a temperature compensation circuit in the future. As such, several devices were cycled through various temperatures ranging from $25-80{ }^{\circ} \mathrm{C}$ using hotplate, and the resulting changes in resistance values 
were measured directly between the two pads of the temperature sensor using a digital multimeter. The measurement temperature range was chosen as not to exceed the normal water condition during real application. The experimental setup for temperature sensor characterisation is shown in Figure 4.

The second characterisation was performed to study the response of the $\mathrm{pH}$ sensor against various $\mathrm{pH}$ solutions at various temperatures. The sensor response was measured in terms of its potential difference between the reference and working electrodes while exposed to a known $\mathrm{pH}$ solution. For this purpose, solutions having $\mathrm{pH}$ values of $2.5,5.5,9.5$, and 11.5 haven been prepared using Kangen Water ${ }^{\circledR}$. As a comparison, the potential difference of these solutions were measured using commercial $\mathrm{pH}$ meter (Lutron YK-2005WA) prior to performing the sensor characterisation.

\section{Results and analysis}

\subsection{Ruthenium based temperature sensor}

Figure 5 shows a typical response of resistance changes against temperature variation from three $\mathrm{RuO}_{2}$ based temperature sensors. It must be noted that although batch fabricated, each sensor should show slight variation in their characteristics, and thus analysis must be done on each individual device. The aim of temperature sensor characterisation was to find a linear relationship between resistance and temperature, such that

$$
\mathrm{R}_{\mathrm{T}}=\mathrm{R}_{0}(1+\alpha \Delta \mathrm{T})
$$

where $R_{T}$ is resistance at temperature $T, R_{0}$ is resistance at reference temperature, and $\alpha$ is the temperature coefficient of resistance of the $\mathrm{RuO}_{2}$ material. Equation (2) is represented by the linear trend line for each sensor data set, and if the reference temperature is taken at $0{ }^{\circ} \mathrm{C}$, therefore $\mathrm{R}_{0} \alpha$ is the same as the gradient and $\mathrm{R}_{0}$ is the constant value of the trendline equation.

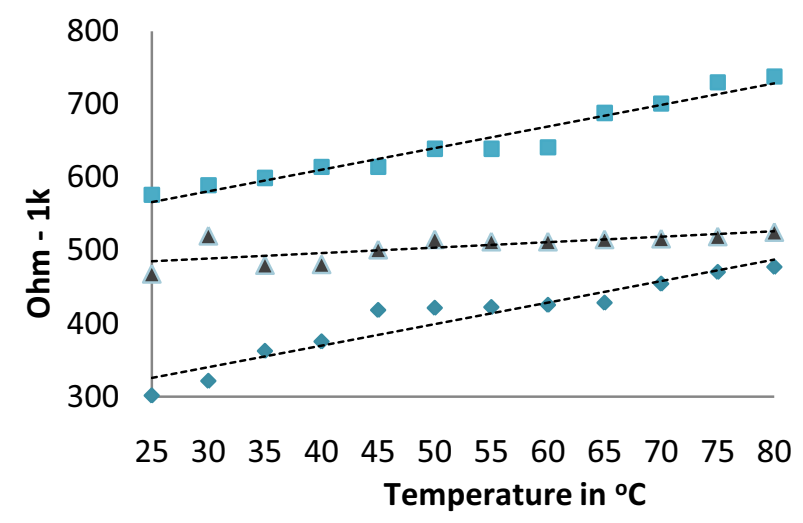

Figure 5. Typical response of resistance changes against temperature variation between $25-80^{\circ} \mathrm{C}$ for three temperature sensor chips. The trendline was generated using Microsoft Excel.

Tabel 1 summarises the values of $\mathrm{R}_{0}$ and $\alpha$ for three $\mathrm{RuO}_{2}$ based sensors fabricated on the same $\mathrm{Al}_{2} \mathrm{O}_{3}$ subtrate. Once the resistance of a liquid is measured by the sensor, its corresponding temperature can be determined by substituting the values of $\mathrm{R}_{0}$ and $\alpha$ from Tabel 1 into Equation (2).

Table 1. The measured values of $\mathrm{R}_{0}$ and $\alpha$ for three $\mathrm{RuO}_{2}$ based temperature sensors

\begin{tabular}{|c|c|c|}
\hline Chip \# & $\mathbf{R}_{\mathbf{0}} \mathbf{( k O h m )}$ & $\left.\boldsymbol{\alpha ( 1 /}{ }^{\mathbf{}} \mathbf{C}\right)$ \\
\hline A & 1.551 & 0.009501 \\
\hline B & 1.481 & 0.005262 \\
\hline C & 1.310 & 0.011227 \\
\hline
\end{tabular}

\subsection{The $\mathrm{pH}$ sensor}

The response of the $\mathrm{pH}$ sensor under various known $\mathrm{pH}$ solutions at temperature $25{ }^{\circ} \mathrm{C}$ is displayed in Figure 6. It can be seen that for acid solutions (low $\mathrm{pH}$ values) the sensor exhibits a net positive potential difference, whereas for base solutions (high $\mathrm{pH}$ values) the sensor shows a net negative response. This means that the response behaves according to the Nernstian equation:

$$
\mathrm{E}-\mathrm{E}_{0}=-0.05916 \mathrm{pH}
$$

where $\mathrm{E}-\mathrm{E}_{0}$ is the measured potential difference of the $\mathrm{pH}$ sensor. The slope of the linear trendline generated by the graph is $-52.97 \mathrm{mV} / \mathrm{pH}$, which shows the sensitivity of the fabricated sensor.

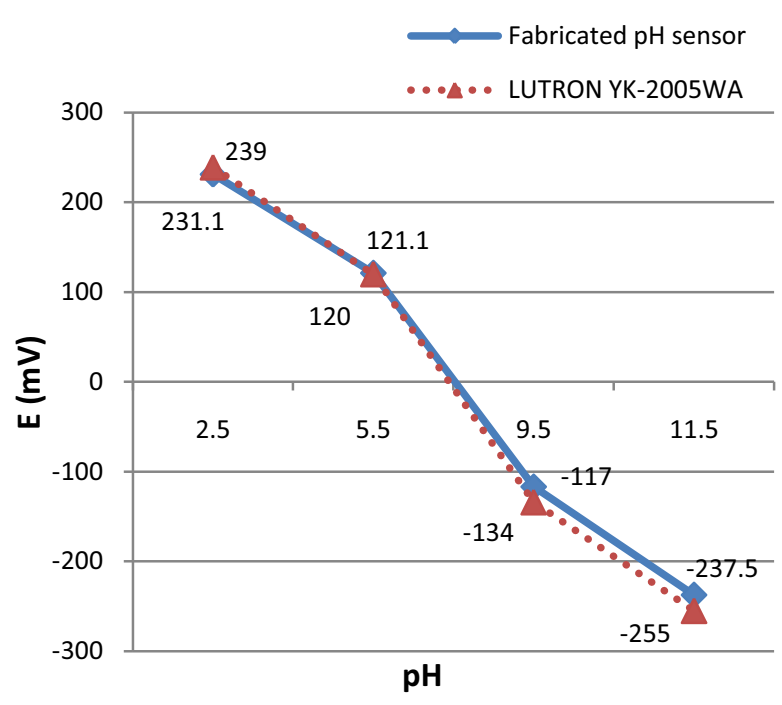

Figure 6. The measured potential difference of the $\mathrm{pH}$ sensor at various known $\mathrm{pH}$ solutions, at temperature of $25^{\circ} \mathrm{C}$.

As a comparison, also in Figure 6 it is shown the measured potential difference of the solutions taken using commercial $\mathrm{pH}$ meter. The meter has a measured sensitivity of $-56 \mathrm{mV} / \mathrm{pH}$. The minor difference indicated that the chlorinated $\mathrm{Ag} / \mathrm{AgCl}$ reference electrode can serves as an alternative to the commercially available $\mathrm{Ag} / \mathrm{AgCl}$ pastes. 
Figure 7 shows the dynamic response of the sensor at $25{ }^{\circ} \mathrm{C}$, expressed in terms of their potential values against time. It can be seen that the time it takes to get a stable response varies from $10 \mathrm{~min}$ (from $\mathrm{pH} 2.5$ to $\mathrm{pH} 5.5$ ), to 5 min (from $\mathrm{pH} 5.5$ to $\mathrm{pH} 9.5$ ) to $3 \mathrm{~min}$ (from $\mathrm{pH} 9.5$ to $\mathrm{pH} 11.5)$.

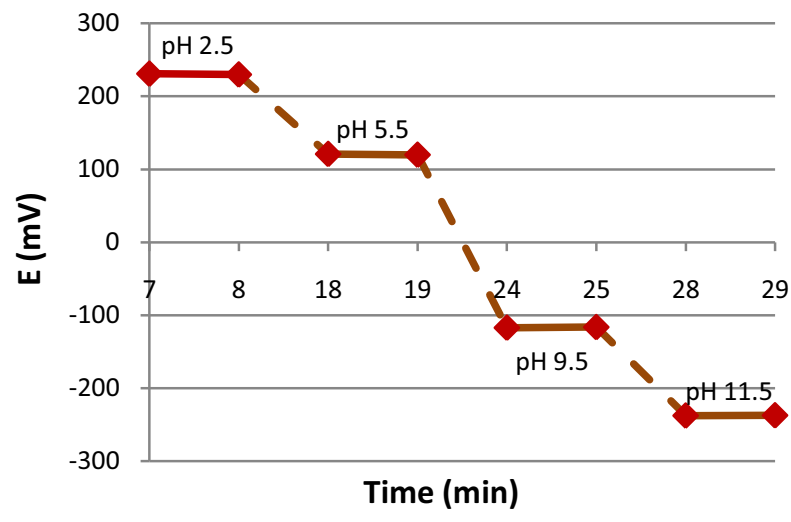

Figure 7. Dynamic response of the $\mathrm{pH}$ sensor at temperature of $25{ }^{\circ} \mathrm{C}$.

The effect of temperature variations from 25 to $65^{\circ} \mathrm{C}$ on the sensor response is shown in Figure 8. The gradients of the linear trendline are $-52.97,-53.17$, and $53.68 \mathrm{mV} / \mathrm{pH}$, for temperature of 25,45 , and $65{ }^{\circ} \mathrm{C}$, respectively. As expected, the gradient increases with increasing temperature, although the increase is still lower than the ideal Nernstian slope at the corresponding temperature.

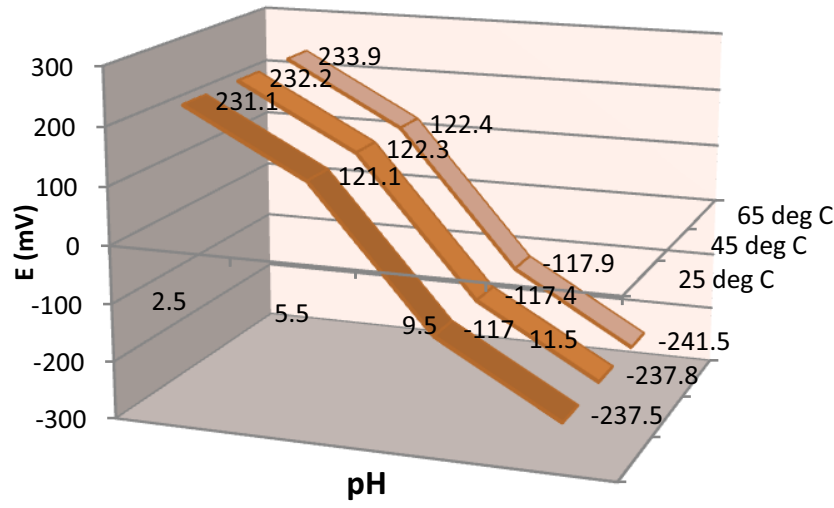

Figure 8. The measured potential difference of the $\mathrm{pH}$ sensor at various $\mathrm{pH}$ and temperature values.

\section{Conclusion}

The design and fabrication of thick film $\mathrm{pH}$ sensor, integrated with a temperature sensor has been described in this paper. The main results indicated that the chlorination of $\mathrm{Ag}$ using $\mathrm{FeCl}_{3}$ has produced a reference electrode, which, along with an $\mathrm{RuO}_{2}$ active layer, is capable of detecting changes in $\mathrm{pH}$ solutions. In fact, at temperature of $25{ }^{\circ} \mathrm{C}$, the sensor has a sensitivity of $52.97 \mathrm{mV} / \mathrm{pH}$, which is close to the ideal Nernstian slope of $-59 \mathrm{mV} / \mathrm{pH}$. The $\mathrm{pH}$ sensor also showed an increasing sensitivity with increasing temperature of the solutions. The Ruthenium based temperature sensor showed a linear response over the temperature range of $25-80{ }^{\circ} \mathrm{C}$. Although fabricated on the same substrate, the measured $\mathrm{R}_{0}$ and $\alpha$ for the temperature sensor has indicated variation due to the nature of thick film processing technology.

To obtain the right $\mathrm{pH}$ reading, it is necessary that a temperature compensation circuit be developed in the future work.

\section{Acknowledgment}

The authors greatly acknowledged the financial support provided by LIPI under the Superior Research Program (Riset Unggulan) 2015 with the project title of Development of Functional Material for Electronics Application.

\section{References}

1. M. Barabde, S. Danve, Real time water quality monitoring system, Int. J. Innov. Res. Comp. Comm. Eng., 3, 6 (2015), pp. $5064-5069$.

2. G. Xu, W. Shen, X. Wang, Applications of wireless sensor networks in marine environment monitoring: A Survey, Sensors, 14 (2014), pp. 16932 - 16954.

3. D. S. Simbeye, S. F. Yang, Water quality monitoring and control for aquaculture based on wireless sensor networks, J. Network., 9, 4 (2014), pp. 840 - 849.

4. Y. Zhang, W. Yang, D. Han, Y. - I. Kim, An integrated environment monitoring system for underground coal mines-Wireless sensor network subsystem with multi-parameter monitoring, Sensors, 14 (2014), pp. 13149 - 13170.

5. R. M. - M'a nez, J. Soto, E. G. - Breijo, L. Gil, J. Ib'ãnez, E. Gadea, A multisensor in thick-film technology for water quality control, Sensor. Act. A., 120 (2005), pp. $589-595$.

6. P. N. Patil, D. V. Sawant, R. N. Deshmukh, Physicochemical parameters for testing of water - A review, Int. J. Env. Sci., 3, 3 (2012), pp. $1194-1207$.

7. T. Y. Kim, S. A Hong, S. Yang, A solid-state thinfilm $\mathrm{Ag} / \mathrm{AgCl}$ reference electrode coated with graphene oxide and its use in a $\mathrm{pH}$ sensor, Sensors, 15 (2015), pp. 6469 - 6482.

8. J. C. B. Fernandes, E. V. Heinke, Alternative strategy for manufacturing of all-solid-state reference electrodes for potentiometry, J. Sens. Sens. Syst., 4 (2015), pp. $53-61$.

9. H. Mamat, N. Firdaus, A. Rahim, W. Saedah. S. M. Salleh, A. Jalar, The characterization of $\mathrm{pH}$ sensor over temperature, Proc. 2nd Int. Con. Mech. Elect. Mecha. Eng., (2013), pp. $171-173$.

10. M. Glanc, M. Sophocleousa, J.K. Atkinson, E. Garcia-Breijo, The effect on performance of 
fabrication parameter variations of thick-film screen printed silver/silver chloride potentiometric reference electrodes, Sensor. Act. A., 197 (2013), pp. 1 - 8.

11. A. Simonis, T. Krings, H. Lüth, J. Wang, M. J. Schöning, A „Hybrid“ thin-film $\mathrm{pH}$ sensor with integrated thick-film reference, Sensors, 1 (2001), pp. $183-192$.

12. L. Tymecki, S. Glab, R. Koncki, Miniaturized, planar ion-selective electrodes fabricated by means of thickfilm technology, Sensors, 6 (2006), pp. $390-396$.

13. G. V. -Ramírez, M. T. R. -Silva, M. P. -Pardavé, M. R. -Romo, Design and Construction of Solid State $\mathrm{Ag} / \mathrm{AgCl}$ Reference Electrodes Through Electrochemical Deposition of $\mathrm{Ag}$ and $\mathrm{AgCl}$ Onto a Graphite/Epoxy Resin-Based Composite. Parte 1: Electrochemical Deposition of Ag Onto a Graphite/Epoxy Resin-Based Composite, Int. J. Electrochem. Sci., 6 (2011), pp. 971 - 987.

14. C. -W. Pana, J. -C. Choub, T. -P. Sun, S. - K. Hsiung, Development of the real-time $\mathrm{pH}$ sensing system for array sensors, Sensor. Act. B, 108 (2005), pp. $870-876$.

15. G. M. da Silva, S. G. Lemos, L. A. Pocrifka, P. D. Marreto, A. V. Rosario, E. C. Pereira, Development of low-cost metal oxide $\mathrm{pH}$ electrodes based on the polymeric precursor method, Analyt. Chim. Act., 616 (2008), pp. $36-41$.

16. D. K. Maurya, A. Sardarinejad, K. Alameh, Recent developments in R.F. magnetron sputtered thin films for $\mathrm{pH}$ sensing applications - an overview, Coatings, 4 (2014), pp. $756-771$.

17. P. Kurzweil, Metal oxides and ion-exchanging surfaces as $\mathrm{pH}$ sensors in liquids: State-of-the-art and outlook, Sensors, 9 (2009), pp. 4955 - 4985.

18. A. Fulati, S. M. U. Ali, M. Riaz, G. Amin, O. Nur, M. Willander, Miniaturized $\mathrm{pH}$ sensors based on zinc oxide nanotubes/nanorods, Sensors, 9 (2009), pp. $8911-8923$.

19. L. Manjakkal, K. Cvejin, J. Kulawik, K. Zaraska, D. Szwagierczak, A low-cost pH sensor based on $\mathrm{RuO2}$ resistor material, Nano Hybrids, 5 (2013), pp. 1-15.

20. B. J. Polk, A. Stelzenmuller, G. Mijares, W. MacCrehanb, M. Gaitan, $\mathrm{Ag} / \mathrm{AgCl}$ microelectrodes with improved stability for microfluidics, Sensor. Act. B, 114 (2006), pp. $239-247$. 